\title{
Learning Management and Its Effect on Improving the Quality of Education
}

\author{
Daman Rasman Syarif Hidayat \\ Universitas Indraprasta PGRI Jakarta, Indonesia \\ Email:daman@unindra.ac.id
}

\begin{abstract}
The rapidly changing time has brought changes, including education, to every aspect of life. Education must constantly make changes to improve the quality of education as one of the formal educational institutions for the community. In this study the types of case studies are qualitative. Interviews and literary studies, field observations, and documentation were used for data collection techniques in this study. In this study, the analysis coincided with data collection on the ground. The investigator reduces data obtained in the field by analyzing the data, sorting each information by the focus of research and drawing conclusions in each direction. This study shows that improvements in the quality of education must be based on alternative management of schools. This promotes the development of the concept of quality management based on schools. This alternative management allows schools to be independent and regulated to improve the quality of education but still refers to national policies.
\end{abstract}

Keywords: Management, School, Improvement, Quality.

\section{A. INTRODUCTION}

The program to improve the quality of education is still experiencing problems. This is based on the fact that the quality of graduates is still low, lectures are less effective and efficient, and many lecturers do not understand how to learn effectively and efficiently in continuing education (Akhmedov, 2021). The rate of drop out is still high, there is no change in the education system and there is an enormous population. In the same way, science and technology developments have brought about changes in nearly every aspect of human life. Only efforts to master and enhance science and technology can solve various problems (Al-Ibrahim, 2014). These changes have brought people to an era of increasingly fierce global competitors and the benefits for human lives (De Grauwe, 2005). We as a nation must continue to develop and improve the quality of its staff in order to play a role in international competition (Hasanudin \& Awaloedin, 2020). Improve the quality of human resources is therefore a reality that must take place in the development process in a planned, guided, intense, effective and efficient manner (Hopkins, 2015).

Improving the quality of education is essentially a strategy to improve the quality of education by giving the authority and responsibility for decision-making 
to the head of education by involving individual participation, both educational personnel and community members (Hurts, 1981). Quality improvement is hard work that must get support from all education citizens (Irmayani, Wardiah \& Kristiawan, 2018). The quality of education is not only seen from how much the education gets achievements. The quality of education is not necessarily only seen from the graduates produced and can continue at certain levels and types of instruction (Kellaghan \& Greaney, 2001). However, the quality of education is also determined by other factors, namely how the teaching and learning process is carried out in education, how education is managed in providing services to educate consumers, and several other factors that need to be considered (Komalasari, Arafat \& Mulyadi, 2020).

Education that wins the competition in the future is education that can quickly respond to changes. Education is expected to make changes designed to be more responsive to the environment (Nurulandari \& Adnyana, 2019). This means that changes need to be made by an education according to the environment's needs so that it is not abandoned by the community (Nurwulandari, Hasanudin \& Melati, 2021). For this reason, the role of a leader is needed in an organizationprimarily, it is part of helping the change process (Sharabi, 2013). In addition to his indispensable role in the change process, the head of education must also have a mature strategy so that these changes can be realized by the birth of innovations that impact improving the quality of education in education (Sriwongchai \& Cookhampaeng, 2015).

Education is important in terms of human resources quality and improves the quality of human resources (Van der Bij \& Ten, 2016). Improving education quality is an inclusive process to improve human resources quality (Verspoor, 2008). The Government, together with the private sector, has worked together and continually to achieve this mandate in recognizing the importance of the improved quality of human resources process through different efforts to promote higher quality education including the creation and improvement of curricular and assessment systems, improvements to the education facilities and development of a (Wahyudi \& Pangestuti, 2017).

Planning is the selection and determination of activities, then what to do, when, how and by whom. Planning is a process that does not end when the plan has been established; projects must be implemented. At any time during the implementation and monitoring process, plans may need improvement to remain functional. "Re-planning" can sometimes be a critical factor in being able to adapt to new situations and conditions as quickly as possible (Zin, Sakat, Ahmad \& Bhari, 
2013).

Organizing is compiling an organizational structure following the goals of the organization, its resources, and the environment surrounding it. Departmentalization and division of labor are two key aspects of the administrative structure process. Departmentalisation consists of a grouping of work activities in order to carry out similar related activities together. This is reflected in an organization's formal structure and can be seen or stated by the organisation's chart. The division of labor is a breakdown of job tasks in order to enable each individual in the organisation. Both of these aspects underpin the organizing of an organization for the efficient and effective achievement of its objectives.

Quality education can be based on process quality and the quality of the product. In terms of function, education is called quality. If the process of teaching and learning is successful, students undergo a meaningful learning process. Appropriate resources are available (human, funds, facilities, infrastructure). Naturally, the quality of the input also influences this. Quality products are also produced logically through a quality education process.

\section{B. METHOD}

In this study the types of case studies are qualitative. Interviews and literary studies, field observations, and documentation were used for data collection techniques in this study. In this study, the analysis coincided with data collection on the ground. The investigator reduces data obtained in the field by analyzing the data, sorting each information by the focus of research and drawing conclusions in each direction. Triangulation techniques (sources and methods/technics), observations and member checks are applied to check the validity of the data used in this study.

\section{RESULT AND DISCUSSION}

\section{Student Management}

The management of students aims to regulate student affairs in order to enjoy the smooth, orderly and regular functioning of the learning activities and to achieve the school's objectives. In order to accomplish this objective, the student management has at least three major tasks, namely the acceptance and progress of new students, and development of guidance and discipline. Student management can be interpreted as regulating students from school students to graduates. What is directly handled are aspects relating to students. On other elements besides students, it is intended to provide the best possible service to students.

Student management is a service that focuses on the management, supervision, and usefulness of students in the classroom and outside the school, 
such as introduction, enrollment, individual services such as the development of the overall ability of interest and needs until he matures in school. Student management can also be interpreted as managing all matters relating to students in a school, starting from planning, student admissions, and coaching. Students are in school until students complete their education at school.

In other words, student management is the whole process of organizing cooperative efforts in student affairs to achieve learning objectives in schools. Thus, student management is not only in the form of student recording activities but includes broader aspects, which are operationally used to assist students' smooth growth and development through the educational process.

\section{Student Planning}

Student planning is an activity to think about things that must be done regarding students at school, both since students will enter school or graduate from school. What is planned is the things done regarding the acceptance of students to the formulation of students. The planning steps of students begin with estimates, formulation of objectives, programming, scheduling, and financing.

Planning for students involves new student admissions, graduation, number of dropouts, and transfers. Specifically, regarding students' planning, it will be directly related to the admissions activities and the process of recording or documentation personally of students, which cannot be separated from the recording or documentation of learning outcomes data and other aspects needed in curricular and co-curricular activities. The first step is planning for students, including activities, analysis of student needs, student recruitment, student selection, orientation, student placement, and recording and reporting. In connection with the above, reasonable planning steps are needed starting from student admissions to class management, to provide optimal services to students.

\section{Student Admission}

Acceptance of new students is one of the essential student management activities. The operational policy of student admissions also contains a registration and selection or screening system applied to students. In addition, the student admission policy also includes the time of registration, when it starts, and when it ends. Furthermore, the student admission policy must also contain the personnel that will be seen in students' selection and acceptance registration. This student admission policy can be made based on the instructions given by the City or City Education Office. This instruction must be followed because it was made to get prospective students as desired or silenced.

The selection system with an entrance test is that those who register at a school are required to complete a series of tasks in test questions. If the person concerned can complete a commission based on specific predetermined criteria, 
then he will be accepted. On the other hand, if they cannot complete the task based on predetermined criteria or rules, they are not accepted as students.

The results of research conducted by Imron, in the recruitment of new students, the problem is that all school-age children in the area around the school cannot accommodate. The contributing factor is the limited school equipment available. The alternative solution is to distribute the school-age children who cannot be adapted to other elementary schools. Another problem in the recruitment of students is that there are children who are less than six years old, but their parents are still adamant about being accepted in elementary school. The contributing factor is that parents are impatient with their children's education. As an alternative solution, the principal and the teacher provide understanding to parents regarding the rules for recruiting new students.

Things that affect the admissions strategy are the excellence and diversity of the school. The committee for the admission of new students needs to show the excellence and diversity of the school so that the community is interested in sending their children to school because the quality of the school is of a higher level than other schools.

\section{Student Orientation}

Student orientation is the activity of accepting new students by introducing the situation and condition of the educational institution where the student is studying. The purpose of holding orientation activities for students is to actively understand and obey all the rules that apply at school to participate in activities organized by the school. Students are ready to face their new environment physically, mentally, and mentally emotionally to feel at home in the learning process at school and adjust to school life.

The school environment where you learn also affects the level of success in learning. Teacher quality, teaching methods, curriculum suitability with children's abilities, state of school equipment facilities, room conditions, number of students per class, implementation of rules and regulations can affect student interest in learning and learning outcomes. The school environment consists of several essential school components, broadly divided into physical and non-physical environments. The physical environment consists of school facilities, school infrastructure, libraries, classrooms, buildings, and school equipment. The non-physical school environment includes interactions between teachers and students, students and other students.

\section{Grouping of Students}

Principals and teaching staff need to be aware of the importance of identifying students in the learning process. The real action that the institution 
must take for this is that in the management of the school's annual program, student identification activities can be accommodated in the planning and implementation, not only there but because this process is sustainable and continuous, aka evaluation in the context of improvement and upgrading. Necessary. The purpose of this identification is actually to recognize the potential of students. Based on this potential, students are then grouped according to the giftedness of each student.

The integration function in the grouping of students is carried out based on age, gender, and so on. The operation of differences in the group of students is carried out based on individual differences, such as talent, ability, interest, and so on. In addition to these two considerations, several considerations, among others, that need to be considered are grouping based on friendship, based on achievement, based on ability and talent, based on attention and interest, the last one based on intelligence.

Differences in the level of ability among students in learning are often found, including economic skills, social skills, artistic skills, and especially intellectual skills. According to the level of academic knowledge, for example, there are at least three levels, namely brilliant students, moderate students, and weak students, so they are always left behind by their friends. Faced with the reality of these different levels of ability, a manager may carry outplacement test activities by grouping them into specific categories. Class A accommodates brilliant students, class B accommodates students with medium knowledge, and class $C$ accommodates weak students. This policy has consequences for allocating students homogeneously. Managers and educators are often faced with a difficult choice between generic or heterogeneous classroom settings. Both have their advantages and disadvantages.

\section{Class Management}

Student management is a service that focuses on supervision arrangements and student services in the classroom and outside the classroom. The stages of student management include analysis of student needs, student recruitment, student selection, student orientation, student placement, student coaching and development, recording and reporting graduation, and alumni. The management of students referred to by the researcher here is management in the classroom, so it is often referred to as classroom management. The teaching process in the school is part of classroom management. Classroom learning can be considered to have four components: Preparation, Presentation, Practice, Performance. A comprehensive approach involving a structuring of the environment of the classroom and of the school is needed to ensure effective class management, to actively monitor students' engagement, to implement classroom rules and routines, to apply behavior-reducing strategies, to collect 
and use data to monitor student behaviour, and to modify classroom management procedures.

\section{Evaluation of Student Learning Outcomes}

Evaluation of learning outcomes for students needs to be done so that their progress is known from time to time. Evaluation of student results is intended to determine the extent to which students have displayed the desired performance. The responsibility for evaluating learning lies with the educator. For evaluation to achieve its objectives, educators need to be guided by the principles of the techniques. Evaluation techniques can be divided into two, namely, test and non-test.

A teacher conducting evaluations depends on students' mastery in specific competencies after following the learning process. The assessment can also aim to find out the learning difficulties of students. The purpose of the evaluation must be clear to provide direction and scope for the development of further assessment. The assessment of students at the primary and secondary education levels is based on objective, integrated, economic, and transparent principles. Educational assessment standards are set through Permendiknas number 20 of 2007, concerning educational assessment standards which include procedures and instruments for assessing student learning outcomes.

\section{Education Quality Improvement}

Quality is a structured process in which the output is improved. Quality is not a magical or complicated thing. The basis of quality is common sense. Quality provides the framework for educators, parents, government officials, community representatives and entrepreneurs to work together to provide students with the means to respond today and in the future to their societal, business and academic challenges. To improve the quality of education, education professionals must be leaders.

For every institution, quality is the primary plan and the most critical task. However, some people think of quality as an enigmatic concept. Quality is seen as confusing and difficult to measure. Quality is one person's view sometimes contradicts quality in another's view. So it is not strange when two experts do not have the same conclusion about creating a good institution.

Quality is defined as the specific features of a product which fulfill customer needs and thus satisfy customers. Quality is income-oriented in accordance with this understanding. Higher quality aims at satisfying customers and meeting one's revenue expectations. However, providing a range of better quality types requires investment, which is why financing usually increases. In this sense, better quality usually calls for more costly funding.

The integrated movement for quality in education remains relatively new. 
Before the 1980s, there is little literature with this reference. Several Indonesian universities have tried to reorganize work practice through the Total Quality Management concept (TQM). The method of TQM was introduced in several more schools at the beginning of the 1990s. There are also many quality-related ideas that higher education institutions are well-developed. Schools are constantly investigating and implementing ideas.

Quality management is a tool for educators to adapt to the forces of change affecting the education system. Our education community already has the knowledge required to improve the education system. The biggest problem today for teachers is the failure to deal with a failing system. It will serve as a means of developing or implementing new educational processes that improve the quality of education for education professionals.

An effective school that is oriented to the quality of education requires a serious commitment to quality improvement, is long-term, and requires the use of specific equipment and techniques. High dedication to quality must support this commitment through continuous process improvement by all parties. Aspects and indicators of the management of educational institutions can be carried out and directed to high quality. Achieving this quality must be an integration of all stakeholder desires and participation in reaching the final result. Some of the steps taken to improve the quality of education include:

\section{Input Quality Improvement}

Educational input is something that must be available for the educational process to take place. Something that must be available is inhuman and nonhuman resources, software, and expectations to guide the ongoing educational process. Human resource inputs include principals, teachers, counselors, students, and employees. At the same time, the input of non-human resources includes, among others, equipment, supplies, funds, materials, and others.

\section{Human Resources}

It is not easy and simply to develop the quality of human resources (HR) as it requires profound and widespread understanding of the formation of core concepts in the development of institutions and funding as well as careful calculations. An effort can be made through various channels, including education, to develop and improve the quality of human resources. This education is a way of improving people's quality and emphasizes the formation of fundamental features like faith and justice, personality, intelligence, discipline, creativity, etc.

Educators and education staff, the most important educators, have their personal resources in the educational world. The task of educators to guide and educate students to have a Muslim personality brings significant consequences 
for educators, among others, educators must set an example for students, among others, have deep scientific insight, are willing to add education to meet the minimum standard requirements for eligibility as educators. And ready to participate in various scientific activities.

\section{Facilities and Infrastructure}

Article 45 of Article 20 of 2003 contains the importance of educational establishments and infrastructure. Law of the Republic of Indonesia Article 45 provides that every unit for formal and non-formal education provides infrastructure and facilities that respond to educational requirements following the expansion and development of the physical, intellectual, social, emotional and student obligation.

The government also provides that all academic units must have facilities that include: furnishings, educational equipment, books and other learning resources; consumer products and equipment necessary to support a proper and sustainable learning process. Education facilities, infrastructure and infrastructure are governed in the government. Every academic unit should consist of land, classes, leadership rooms, rooms for teachers, libraries, laboratory rooms, canteens, sports and worship facilities, playgrounds, play areas, and other areas that are required in order to support an orderly learning process. And sustainable. And sustainable.

Education and infrastructure management has a responsibility to regulate and maintain educational facilities and infrastructure in order to optimal and meaningful contributions to the educational process. These activities include planning, procurement, monitoring, storage, stockpiling, deletion and structuring. Research results by Maulida et al. show that the education and infrastructure planning process includes:

a. Procurement is the process of designing efforts to purchase, rent, borrow, land plots, recycling, reconditioning/rehabilitation, distribution or manufacture of equipment and supplies following school needs;

b. Equity carried out openly and transparently to users involving several employees to solve problems and suitability of recipients of facilities with an equalization agenda;

c. Utilization of facilities and infrastructure has led to achieving goals, although, in its implementation, the use of educational facilities and infrastructure often experiences overlaps between instructions and technical service. The use of tools for all classes can be done by bringing to the class that needs it alternately or students who will use it come to a particular room. Like getting tools to class or bringing students into the tool room, there are pros and cons. Tools are brought into the classroom; 
there is a permanent class, and students come to the rooms where the class goes (class is a group of children who are at the same time under the guidance of a teacher).

\section{Learning Process}

Learning is a conscious and systematic effort. Planning and implementation of learning are expected to have specific goals set. Thus, the learning process manifested in the interaction of students with teachers and sources of knowledge must be directed so that students can gain meaningful experiences. School as a place of learning that provides quality services through varied learning strategies, continuous assessment, and fast and appropriate follow-up encourages student participation in learning and pays attention to student attendance, implementation of student assignments, and the sustainability of their projects.

Learning is the essence of education. Furthermore, if the learning process is conducive, providing inspiration, motivation, enthusiasm, and learning creations will lead to educational success. The building may be simple, the office space may be narrow, and the position of the Islamic educational institution may be in the outskirts, as long as the learning system is truly conducive and is still able to ensure the continuity of the educational process properly. Why are magnificent buildings, luxurious offices and located in the middle of a big city? If the learning system is stealthy, it will certainly not be able to deliver educational success. This is because education requires an intensive process, and there is no instant education.

The main activity of the school is the learning process. According to characteristics of the subjects, students, teachers and the natural conditions of resources available at school, schools are given the freedom to choose the most effective learning and teaching methods, methods and techniques. The learning process focused on students can empower students by emphasizing activity in student learning rather than teacher education.

\section{CONCLUSION}

The different conditions of the school environment and the diversity of learning needs of students, combined with highly complex geographical conditions in Indonesia. It is therefore necessary to look for alternative school management in order to improve the quality of education. This promotes the development of the concept of quality management based on schools. This alternative management allows schools to be independent and regulated to improve the quality of education but still refers to national policies. The result of this program is that different parties are very committed to the goal of 
improved quality of education, namely, parents/ the community, lecturers, leaders of the schools, students and other staff on the one hand, and the government on the other. The schools' strategies include self-evaluation to assess the strengths and weaknesses of their school in the implementation of the management concept.

\section{REFERENCES}

1. Akhmedov, B. A. (2021). Innovative cluster model for improving the quality of education. Academic Research in Educational Sciences, 2(3).

2. Al-Ibrahim, A. (2014). Quality management and its role in improving service quality in the public sector. Journal of Business and Management Sciences, 2(6), 123147.

3. De Grauwe, A. (2005). Improving the quality of education through school-based management: Learning from international experiences. International review of education, 51(4), 269-287.

4. Hasanudin, H. (2021). The Effect of Inflation, Exchange, SBI Interest Rate and Dow Jones Index on JCI on IDX 2013-2018. Budapest International Research and Critics Institute (BIRCI-Journal): Humanities and Social Sciences, 4(2), 2063-2072.

5. Hasanudin, H., \& Awaloedin, D. T. (2020). Pengaruh Current Ratio, Debt To Equity Ratio Dan Net Profit Margin Terhadap Return Saham Pada Perusahaan Jasa Sub Sektor Telekomunikasi Yang Terdaftar di BEI Periode 2012-2018. Jurnal Rekayasa Informasi, 9(1), 6-19.

6. Hopkins, D. (2015). Improving the quality of education for all: A handbook of staff development activities. Routledge.

7. Hurst, P. (1981). Some issues in improving the quality of education. Comparative Education, 17(2), 185-193.

8. Irmayani, H., Wardiah, D., \& Kristiawan, M. (2018). The strategy of SD Puri in improving educational quality. International Journal of Scientific $\mathcal{E}$ Technology Research, 7(7), 113-121.

9. Kellaghan, T., \& Greaney, V. (2001). Using assessment to improve the quality of education (p. 98). Unesco, International Institute for Educational Planning.

10. Komalasari, K., Arafat, Y., \& Mulyadi, M. (2020). Principal's Management Competencies in Improving the Quality of Education. Journal of Social Work and Science Education, 1(2), 181-193.

11. Nurwulandari, A., \& Adnyana, I. (2019). Did Inter-Regional Trade Agreements Bring Mutual Benefits? An Empirical Scheme of Indonesian Commodity Exports in Asean-China Free Trade Area. International Journal of Financial Research, 10(6), 241-249. 
12. Nurwulandari, A., Hasanudin, H., \& Melati, M. (2021). Market Reactions on Corporate Actions in Growing and Nongrowing Energy-Consuming Companies. International Journal of Energy Economics and Policy, 11(3), 290-295.

13. Sharabi, M. (2013). Managing and improving service quality in higher education. International Journal of Quality and Service Sciences.

14. Sriwongchai, A., Jantharajit, N., \& Chookhampaeng, S. (2015). Developing the Mathematics Learning Management Model for Improving Creative Thinking in Thailand. International Education Studies, 8(11), 77-87.

15. Van der Bij, T., Geijsel, F. P., \& Ten Dam, G. T. M. (2016). Improving the quality of education through self-evaluation in Dutch secondary schools. Studies in Educational Evaluation, 49, 42-50.

16. Verspoor, A. M. (2008, May). The challenge of learning: Improving the quality of primary education in sub-Saharan Africa. In The changing landscape of education in Africa. Oxford: Symposium.

17. Wahyudi, S., \& Pangestuti, I. R. D. (2017). Managing the Pension Fund to Improve Portfolio Performance: An Empirical Study on Employer Pension Funds In Indonesia.

18. Wahyudi, S., Hasanudin, H., \& Pangestutia, I. (2020). Asset allocation and strategies on investment portfolio performance: A study on implementing employee pension fund in Indonesia. Accounting, 6(5), 839-850.

19. Zin, M. Z. M., Sakat, A. A., Ahmad, N. A., \& Bhari, A. (2013). Relationship between multimedia technology and education in improving learning quality. Procedia-Social and Behavioral Sciences, 90, 351-355. 